\title{
Probiotics' effects on the incidence of nosocomial pneumonia in critically ill patients: a systematic review and meta-analysis
}

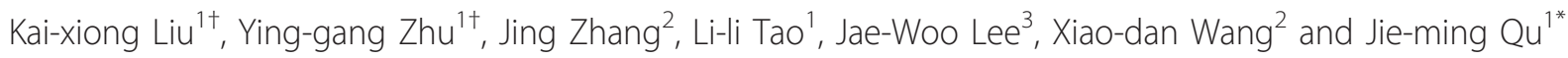

\begin{abstract}
Introduction: To evaluate the efficacy of probiotics in preventing nosocomial pneumonia in critically ill patients.

Methods: We searched PubMed, EMBASE, and the Web of Science for relevant studies. Two reviewers extracted data and reviewed the quality of the studies independently. The primary outcome was the incidence of nosocomial pneumonia. Study-level data were pooled using a random-effects model when $P^{2}$ was $>50 \%$ or a fixed-effects model when $P^{2}$ was $<50 \%$.

Results: Twelve randomized controlled studies with a total of 1,546 patients were considered. Pooled analysis showed a statistically significant reduction in nosocomial pneumonia rates due to probiotics (odd ratio $[O R]=0.75$, $95 \% \mathrm{Cl} 0.57$ to $0.97, P=0.03, P^{2}=46 \%$ ). However, no statistically significant difference was found between groups regarding in-hospital mortality $\left(\mathrm{OR}=0.93,95 \% \mathrm{Cl} 0.50\right.$ to $\left.1.74, P=0.82, P^{2}=51 \%\right)$, intensive care unit mortality $(\mathrm{OR}=$ $0.84,95 \% \mathrm{Cl} 0.55$ to $1.29, P=0.43, P^{2}=0 \%$ ), duration of stay in the hospital (mean difference [MD] in days $=-0.13$, $95 \% \mathrm{Cl}-0.93$ to $\left.0.67, P=0.75, P^{2}=46 \%\right)$, or duration of stay in the intensive care units ( $\mathrm{MD}=-0.72,95 \% \mathrm{Cl}-1.73$ to $0.29, P=0.16, P^{2}=68 \%$ ).

Conclusions: The use of probiotics was associated with a statistically significant reduction in the incidence of nosocomial pneumonia in critically ill patients. However, large, well-designed, randomized, multi-center trials are needed to confirm any effects of probiotics clinical endpoints such as mortality and length of ICU and hospital stay.
\end{abstract}

\section{Introduction}

Nosocomial pneumonia (NP) is a common complication in critically ill patients, particularly in patients who are intubated for more than 48 hours, and NP is responsible for significant in-hospital morbidity and mortality [1-3]. When mechanically ventilated patients develop NP, it is known as ventilator-associated pneumonia (VAP) $[1,2]$. Multiple hospital-associated risk factors for NP have been identified. These risk factors are thought to contribute to increased bacterial colonization of the aerodigestive tract and facilitate the entry of pathogenic bacteria into the lower respiratory tract [4].

\footnotetext{
* Correspondence: jmqu64@yahoo.com.cn

† Contributed equally

'Department of Pulmonary Medicine, Huadong Hospital, Shanghai Medical

School of Fudan University, 221 Yananxi Road, Shanghai 200040, China

Full list of author information is available at the end of the article
}

Considerable efforts have been made to evaluate methods for reducing NP. For example, selective digestive tract decontamination in critically ill patients has been shown to reduce the occurrence of NP; however such decontamination has also been associated with increased rates of antimicrobial resistance $[5,6]$. Several experimental and clinical studies have suggested a promising effect of probiotics on preventing NP in critically ill patients [7-10].

Probiotics are commercially available microorganisms that when ingested as individual strains or in combination may offer potential health benefits to the host [11]. Prebiotics are non-digestible sugars that selectively stimulate the growth of certain bacteria colonies. The combination of pre- and probiotics has been designated as synbiotics. It is hypothesized that probiotics could potentially reduce the incidence of NP in critically ill patients through various local and systemic effects that minimize colonization by
C Biomed Central

(c) 2012 Liu et al.; licensee BioMed Central Ltd. This is an open access article distributed under the terms of the Creative Commons Attribution License (http://creativecommons.org/licenses/by/2.0), which permits unrestricted use, distribution, and reproduction in any medium, provided the original work is properly cited. 
more virulent species or optimize host immune defenses. These effects include reducing overgrowth of potentially pathogenic microorganisms, enhancing gut barrier function, reducing bacterial translocation, and up-regulation of immune functions [12-19].

To date, clinical research concerning the effects of probiotics in critically ill patients have provided conflicting results, with some suggesting clinical benefit [20-29], and others showing no benefit [30-33]. More recently, one study showed that probiotics therapy led to a significant reduction in VAP rates among treated patients [22]. However, another study showed that daily prophylactic administration of probiotics was not effective for critically ill patients, notably for those with non-severe sepsis [30].

Therefore, we performed a systematic literature review and meta-analysis to investigate the effects of probiotics in critically ill patients using incidence of NP as the primary outcome, and mortality, length of stay in the ICU and in hospital, and adverse outcomes as secondary outcomes.

\section{Materials and methods}

\section{Data sources and search strategy}

To identify studies for inclusion in this review, two authors independently searched PubMed, the Cochrane Central Database of Controlled Trials, and EMBASE for relevant studies published up to January 2012. The search was limited to studies conducted in humans. No language restriction was imposed. Search terms were individualized for each database. Search terms used included: ['pneumonia' OR 'critically ill' OR 'intensive care' OR 'trauma' OR 'pancreatitis' OR 'surgical patients'] AND ['probiotics' OR 'prebiotics' OR 'synbiotics' OR 'lactobacillus' OR 'bifidobacterium']. We also searched the proceedings of major relevant conferences, trial databases, the reference lists of identified trials, and major reviews.

\section{Study selection}

Two reviewers (KXL and YGZ) independently screened studies for inclusion, retrieved potentially relevant studies, and determined study eligibility. Any discrepancies were resolved by consensus. Analysis was restricted to double-blind, randomized controlled trials (RCTs). For this meta-analysis, we considered those RCTs that compared administration of probiotics vs. placebo in critically ill patients (such as those admitted to an ICU or having recently undergone abdominal or another major surgical procedure), and that reported the incidence of NP or VAP. Probiotics could be administered either alone or in combination with prebiotics.

\section{Data extraction}

Two authors independently extracted data from all of the enrolled studies. Extracted data included study design (for example, year conducted, sample size), patient characteristics, study methodology (for example, eligibility criteria, method of randomization and blinding), intervention (for example, type of probiotic agent, dose, route of its administration and duration), and clinical outcomes. The primary outcome was the incidence of NP. We used the authors' definitions for NP if they included clinical and radiological criteria. Secondary outcomes were mortality, length of stay in ICU and in hospital, and reports of adverse outcomes.

\section{Quality assessment}

We formally assessed the methodological quality of each trial using the Jadad score [34], which incorporates randomization, blinding, and attrition to derive a score of 0 to 5; higher scores indicate higher quality. Two reviewers (KXL and YGZ) independently appraised the quality of the included trials. Studies were considered to be of low quality if the Jadad score was $\leq 2$ and high quality if the score was $\geq 3$.

\section{Statistical analysis}

The meta-analysis was performed using Review Manager 5.0 (Cochrane Collaboration, Oxford, UK). We computed pooled odds ratios (ORs) and 95\% confidence intervals (CIs) from the adjusted ORs and 95\% CIs reported in the observational studies. We used Cochrane $\mathrm{Q}$ and $I^{2}$ statistics to assess the heterogeneity of study results. We predefined heterogeneity as low, moderate or high with $I^{2}$ values above $25 \%, 50 \%$, and $75 \%$, respectively. In the analysis of heterogeneity, we considered a $P$-value $<0.10$ statistically significant. Study-level data were pooled using a random-effects model when $I^{2}$ was $>50 \%$ or a fixed-effects model when $I^{2}$ was $<50 \%$. Publication bias was assessed by a funnel plot using the occurrence of NP as an endpoint.

\section{Results}

Our search retrieved a total of 131 references. After applying the inclusion criteria, twelve studies were included in this meta-analysis [22-33]. A flowchart for the studies evaluated and the reasons for exclusion are shown in Figure 1.

\section{Study characteristics}

Characteristics of the included studies are summarized in Table 1. A total of 1,546 critically ill patients were included in these studies. All studies were published from 2002 to 2011. Trials were conducted in a diverse array of countries. Most of the trials were carried out at a single center. Four studies recruited patients in general ICUs [22,30-32], eight studies recruited patients in surgical ICUs [23-29,33], one study recruited patients who were scheduled for liver transplantation [26], and one 


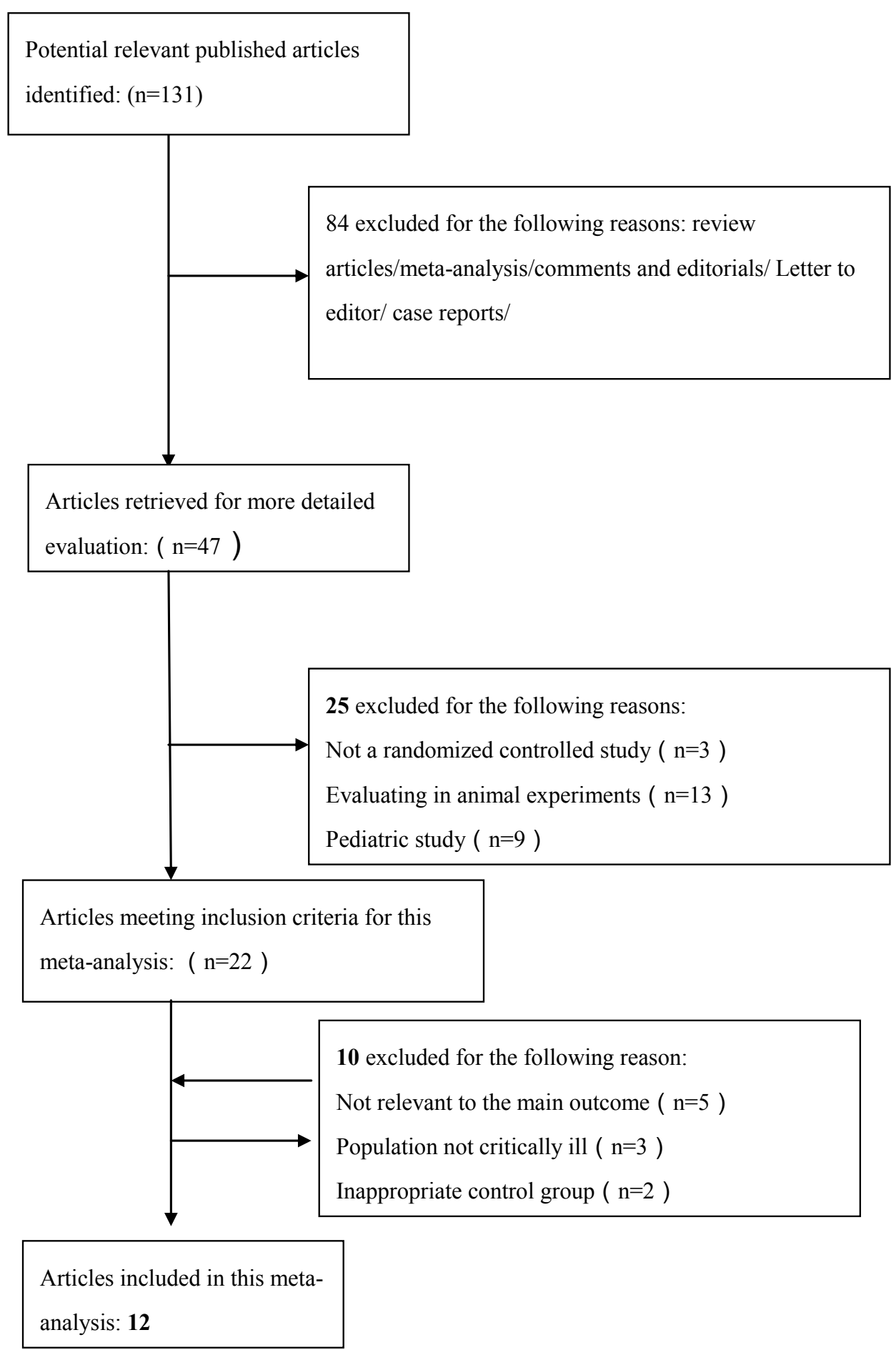

Figure 1 Flow chart of study selection. Pooled ORs were calculated using the Mantel-Haenszel (M-H)Estimator. Study-level data were pooled using a random-effects model when $P^{2}$ was $>50 \%$ or a fixed-effects model when $R^{2}$ was $<50 \%$.

study recruited patients with severe acute pancreatitis [33]. Seven of the twelve clinical trials enrolled patients who required mechanical ventilation (MV) from medical and surgical ICUs [22,23,28-32]. The frequency of probiotic administration ranged from once to twice a day. In the majority of eligible trials, probiotics were administered via nasogastric or orogastric tube [22,23,28-32] until the patient's discharge from the ICU 
Table 1 Characteristics of the study population in various studies

\begin{tabular}{|c|c|c|c|c|c|}
\hline $\begin{array}{l}\text { Study, } \\
\text { year }\end{array}$ & $\begin{array}{l}\text { Study } \\
\text { design }\end{array}$ & Population & $\begin{array}{l}\text { Disease } \\
\text { severity } \\
\text { Score }\end{array}$ & Regimen used & $\begin{array}{l}\text { Route of } \\
\text { administration/ } \\
\text { duration of intake }\end{array}$ \\
\hline $\begin{array}{l}\text { Barraud et } \\
\text { al., } 2010 \\
{[30]}\end{array}$ & $\begin{array}{l}\text { SC } \\
\text { DBRCT }\end{array}$ & $\begin{array}{l}\text { General/all intubated adult patients } \\
\text { under } \mathrm{MV} \geq 48 \text { hours }\end{array}$ & $\begin{array}{l}\text { SAPS } 11: 58.6 \pm \\
17.3 \text { vs. } 60.5 \\
\pm 19.6\end{array}$ & $\begin{array}{l}\text { Ergyphilus (Lactobacillus rhamnosus GG, } \\
\text { Lactobacillus casei, Lactobacillus } \\
\text { acidophilus, Bifidobacterium bifidum) }\end{array}$ & $\begin{array}{l}\text { Enteral feeding tube/ } \\
\text { entire period of MV and } \\
\text { additional days }\end{array}$ \\
\hline $\begin{array}{l}\text { Besselink et } \\
\text { al., } 2008 \\
{[33]}\end{array}$ & $\begin{array}{l}\mathrm{MC} \\
\mathrm{DBRCT}\end{array}$ & $\begin{array}{l}\text { Patients with predicted severe acute } \\
\text { pancreatitis }\end{array}$ & $\begin{array}{l}\text { APACHE II: } \\
8.6 \pm 4.4 \text { vS. } \\
8.4 \pm 4.5\end{array}$ & $\begin{array}{l}\text { Ecologic } 641 \text { (Lactobacillus acidophilus, } \\
\text { Lactobacillus casei, Lactobacillus salivarius, } \\
\text { Lactococcus lactis, Bifi dobacterium } \\
\text { bifidum, and Bifidobacterium } \\
\text { lactis) }\end{array}$ & Nasojejunal tube/28 days \\
\hline $\begin{array}{l}\text { Forestier et } \\
\text { al., } 2008 \\
\text { [31] }\end{array}$ & SC RCT & $\begin{array}{l}\text { General/patients (>18 yrs) requiring MV } \\
>48 \text { hours }\end{array}$ & $\begin{array}{l}\text { SAPS II: } 45 \pm \\
16 \text { Vs. } 44 \pm \\
15\end{array}$ & Lactobacillus caseirhamnosus & $\begin{array}{l}\text { Nasogastric or orogastric } \\
\text { tube/until ICU discharge } \\
\text { or death }\end{array}$ \\
\hline $\begin{array}{l}\text { Giamarellos- } \\
\text { Bourboulis } \\
\text { et al., } 2009 \\
{[23]}\end{array}$ & $\begin{array}{l}\text { MC } \\
\text { DBRCT }\end{array}$ & $\begin{array}{l}\text { Surgical/severe multiple organ injuries } \\
\text { necessitating emergency tracheal } \\
\text { intubation and ventilation support }\end{array}$ & $\begin{array}{l}\text { APACHE ॥: } \\
19.36 \text { vs. } \\
19.36\end{array}$ & $\begin{array}{l}\text { Synbiotic2000 FORTE (Pediococcus } \\
\text { pentosaceus, Leuconostoc mesenteroides, } \\
\text { Lactobacillus paracasei subsp paracasei } \\
\text { and Lactobacillus plantarum) }\end{array}$ & $\begin{array}{l}\text { Nasogastric tube or } \\
\text { through gastostomy/15 } \\
\text { consecutive days post } \\
\text { admission }\end{array}$ \\
\hline $\begin{array}{l}\text { Kanazawa } \\
\text { et al., } 2005 \\
{[24]}\end{array}$ & SC RCT & $\begin{array}{l}\text { Surgical/patients with biliary cancer, } \\
\text { scheduled to undergo combined liver } \\
\text { and extrahepatic bile duct resection } \\
\text { with hepaticojejunostomy }\end{array}$ & NA & $\begin{array}{l}\text { Yakult BL Seichōyaku (Bifidobacterium } \\
\text { breveStrain Yakult, } \\
\text { Lactobacillus casei strain } \\
\text { Shirota) }\end{array}$ & $\begin{array}{l}\text { Intraoperative jejunal } \\
\text { feeding catheter/14 days } \\
\text { post-surgery }\end{array}$ \\
\hline $\begin{array}{l}\text { Knight et al. } \\
\text { 2009, [32] }\end{array}$ & $\begin{array}{l}\text { SC } \\
\text { DBRCT }\end{array}$ & $\begin{array}{l}\text { General/patients (> 16yrs) requiring MV } \\
>48 \text { hours }\end{array}$ & $\begin{array}{l}\text { APACHE II: } 17 \\
\text { (12-23) vs.17 } \\
(12-22)\end{array}$ & $\begin{array}{l}\text { Synbiotic2000 FORTE (Pediococcus } \\
\text { pentosaceus, Leuconostoc mesenteroides, } \\
\text { Lactobacillus paracasei subsp paracasei } \\
\text { and Lactobacillus plantarum) }\end{array}$ & $\begin{array}{l}\text { Nasogastric or orogastric } \\
\text { tube/until } 28 \text { days after } \\
\text { ICU admission, discharge } \\
\text { or death }\end{array}$ \\
\hline $\begin{array}{l}\text { Morrow et } \\
\text { al., } 2010 \\
\text { [22] }\end{array}$ & $\begin{array}{l}\text { SC } \\
\text { DBRCT }\end{array}$ & $\begin{array}{l}\text { General/patients ( }>19 \mathrm{yrs} \text { ) requiring MV } \\
\text { with an endotracheal tube for at least } \\
72 \text { hours }\end{array}$ & $\begin{array}{l}\text { APACHE II: } \\
22.7 \pm 7.5(8- \\
38) \text { Vs. } 23.7 \pm \\
8.0(8-41)\end{array}$ & Lactobacillus rhamnosus GG & $\begin{array}{l}\text { Nasogastric tube/until } \\
\text { extubation, tracheostomy } \\
\text { placement, or death }\end{array}$ \\
\hline $\begin{array}{l}\text { Rayes et al., } \\
2002[25]\end{array}$ & $\mathrm{RCT}$ & $\begin{array}{l}\text { Surgical/patients who were scheduled } \\
\text { for major abdominal surgery }\end{array}$ & NA & Lactobacillus plantarum 299 and fibres & $\begin{array}{l}\text { Nasojejunal tube/7 days } \\
\text { post-surgery }\end{array}$ \\
\hline $\begin{array}{l}\text { Rayes et al., } \\
2005 \text { [26] }\end{array}$ & DBRCT & $\begin{array}{l}\text { Surgical/patients scheduled for liver } \\
\text { transplantation }\end{array}$ & NA & $\begin{array}{l}\text { Synbiotic2000 FORTE (Pediococcus } \\
\text { pentosaceus, Leuconostoc mesenteroides, } \\
\text { Lactobacillus paracasei subsp paracasei } \\
\text { and Lactobacillus plantarum) }\end{array}$ & $\begin{array}{l}\text { Nasojejunal tube/14 days } \\
\text { post-surgery }\end{array}$ \\
\hline $\begin{array}{l}\text { Rayes et al., } \\
2007 \text { [27] }\end{array}$ & $\begin{array}{l}\text { MC } \\
\text { DBRCT }\end{array}$ & $\begin{array}{l}\text { Surgical/patients who were scheduled } \\
\text { for pancreaticoduodenectomy }\end{array}$ & NA & $\begin{array}{l}\text { Synbiotic2000 FORTE (Pediococcus } \\
\text { pentosaceus, Leuconostoc mesenteroides, } \\
\text { Lactobacillus paracasei subsp paracasei } \\
\text { and Lactobacillus plantarum) }\end{array}$ & $\begin{array}{l}\text { Oral (pre-surgery) and } \\
\text { nasojejunal tube (post- } \\
\text { surgery) } / 1 \text { day pre- to } 8 \\
\text { days post-surgery }\end{array}$ \\
\hline $\begin{array}{l}\text { Spindler- } \\
\text { Vesel et al., } \\
2009 \text { [28] }\end{array}$ & SC RCT & $\begin{array}{l}\text { Surgical/multiple injury patients } \\
\text { requiring MV and at least } 4 \text { days stay in } \\
\text { ICU }\end{array}$ & $\begin{array}{l}\text { APACHE II: } 14 \\
\text { (12-19) Vs. NA }\end{array}$ & $\begin{array}{l}\text { Synbiotic2000 FORTE (Pediococcus } \\
\text { pentosaceus, Leuconostoc mesenteroides, } \\
\text { Lactobacillus paracasei subsp paracasei } \\
\text { and Lactobacillus plantarum) }\end{array}$ & $\begin{array}{l}\text { Intragastric tube/until } \\
\text { ICU discharge or death }\end{array}$ \\
\hline $\begin{array}{l}\text { Tan et al., } \\
\text { 2011[29] }\end{array}$ & SC RCT & $\begin{array}{l}\text { Surgical/patients with closed head } \\
\text { injury only; admission within } 24 \text { hours } \\
\text { after trauma ( } 18 \text { to } 60 \text { yrs) }\end{array}$ & $\begin{array}{l}\text { APACHE II: } \\
14.8 \pm 3.6 \text { vS } \\
14.8 \pm 3.6\end{array}$ & $\begin{array}{l}\text { Golden Bifid (Bifidobacterium } \\
\text { longum, Lactobacillus bulgaricus, } \\
\text { and Streptococcus thermophilus) }\end{array}$ & $\begin{array}{l}\text { Nasogastric tube/21 } \\
\text { consecutive days }\end{array}$ \\
\hline
\end{tabular}

APACHE: Acute Physiology and Chronic Health Evaluation; DB: double-blind; ICU: intensive care unit; MC: multicenter; MV: mechanical ventilation; NA: not available; RCT: randomized control trial; SAPS: Simplified Acute Physiology Score; SC: single-center.

or death. In some surgical patients, probiotics were administered via nasojejunal tubes [24-27,33]. The average Jadad score of these studies was 3.5 (range 2.0 to 5.0) (Table 2). Results of the meta-analyses that explored the effects of probiotics on clinical outcomes are shown in Table 3.

\section{Nosocomial pneumonia and subgroup analyses}

Results from twelve trials (1,546 patients) were available to examine the effects of oral probiotics on the incidence of NP. A low level of heterogeneity was found among the identified comparisons $\left(I^{2}=46 \%, P=0.04\right)$. Pooled analysis showed that the use of probiotics was associated with a statistically significant reduction in the incidence of NP in critically ill patients $(\mathrm{OR}=0.75,95 \%$ CI 0.57 to $0.97, P=0.03$ ) (Figure 2).

We also performed subgroup analyses after stratifying trials by critically ill patients requiring MV (see Additional File 1) and surgical critically ill patients (see Additional File 2). Seven studies reported the incidence of VAP [22,23,28-32]. No statistically significant difference in the incidence of VAP was found between patients 
Table 2 Quality of the twelve studies as assessed by the Jadad score [34]

\begin{tabular}{lcccc}
\hline Study & Randomization & Blinding & Withdrawals and dropouts & Quality Score \\
\hline Barraud et al. [30] & 2 & 2 & 1 & 5 \\
Besselink et al. [33] & 2 & 2 & 1 & 5 \\
Forestier et al. [31] & 2 & 2 & 1 & 5 \\
Giamarellos-Bourboulis et al. [23] & 1 & 2 & 0 & 3 \\
Kanazawa et al. [24] & 1 & 1 & 1 & 2 \\
Knight et al. [32] & 2 & 2 & 1 & 5 \\
Morrow et al. [22] & 1 & 2 & 1 & 4 \\
Rayes et al. [25] & 2 & 0 & 1 & 3 \\
Rayes et al. [26] & 2 & 1 & 0 & 4 \\
Spindler-Vesel et al. [28] & 1 & 1 & 1 & 2 \\
Tan et al.[29] & 2 & 1 & & 4
\end{tabular}

Each article was scored using a five-point scale that evaluates randomisation, blinding and completeness of patient follow-up (Jadad scale). One point was given if the study was described as randomised. An additional point was given if the randomisation method was described and was appropriate (for example, computer-generated table of random numbers), whereas a point was subtracted if the randomisation method was described and inappropriate. Similarly, one point was assigned to studies described as double-blinded, two points were assigned to studies for which the double-blinding method was described and appropriate (for example, identical placebo, active placebo,double-dummy) and zero points were assigned to studies for which the double-blinding method was described and inappropriate. One point was given if the article specified the numbers of and reasons for withdrawals and dropouts.

who received probiotics and patient controls $(\mathrm{OR}=0.68$, 95\% CI 0.42 to $\left.1.11, P=0.12, I^{2}=54 \%\right)$. We noted a marginally significant beneficial effect of probiotics on reducing the rate of NP in critically ill surgical patients in a meta-analysis that included eight studies $(\mathrm{OR}=$ $0.67,95 \%$ CI 0.45 to $1.01, P=0.05, I^{2}=41 \%$ ) [23-29,33].

\section{Overall mortality}

Results of nine trials were available for the analysis of mortality during the entire hospital stay [22-27,29,32,33]. A meta-analysis of these trials found that probiotics administration had no effect on overall mortality during the hospital stay $(\mathrm{OR}=0.93,95 \% \mathrm{CI}$

Table 3 Outcome data of the randomized controlled trials included in the meta-analysis (comparison of probiotics versus control)

\begin{tabular}{|c|c|c|c|c|c|}
\hline Study & $\begin{array}{l}\text { Incidence of } \\
\text { NP/VAP, n/N }\end{array}$ & $\begin{array}{l}\text { ICU mortality, } \\
\mathrm{n} / \mathrm{N}\end{array}$ & $\begin{array}{c}\text { In-hospital } \\
\text { mortality, } \\
\text { n/N }\end{array}$ & $\begin{array}{l}\text { Length of ICU stay, median } \\
\text { days (range) }\end{array}$ & $\begin{array}{c}\text { Length of hospital stay, median } \\
\text { days (range) }\end{array}$ \\
\hline Barraud et al. [30] & $\begin{array}{c}23 / 87 \text { vs. } 15 / 80 \\
\text { (VAP) }\end{array}$ & $\begin{array}{c}21 / 87 \\
\text { vs. } 21 / 80\end{array}$ & NA & $18.7 \pm 12.4$ vs. $20.2 \pm 20.8$ & $\begin{array}{c}26.6 \pm 22.3 \\
\text { vs. } 28.9 \pm 26.4\end{array}$ \\
\hline Besselink et al. [33] & $24 / 152$ vs. $16 / 144$ & NA & $\begin{array}{l}24 / 152 \\
\text { vs. } 9 / 144\end{array}$ & $6.6 \pm 17.1$ vs. $3.0 \pm 9.3$ & $\begin{array}{l}28.9 \pm 41.5 \\
\text { vs. } 23.5 \pm 25.9\end{array}$ \\
\hline Forestier et al [31] & $\begin{array}{l}\text { 24/102 vs. } 24 / 106 \\
\text { (VAP) }\end{array}$ & NA & NA & NA & NA \\
\hline $\begin{array}{l}\text { Giamarellos-Bourboulis et } \\
\text { al. [23] }\end{array}$ & $\begin{array}{c}\text { 15/36 vs. } 16 / 36 \\
\text { (VAP) }\end{array}$ & NA & $\begin{array}{l}5 / 36 \\
\text { vs. } 10 / 36\end{array}$ & NA & NA \\
\hline Kanazawa et al. [24] & $0 / 21$ vs. $1 / 23$ & NA & $\begin{array}{c}0 / 21 \\
\text { vs. } 0 / 23\end{array}$ & $\begin{array}{l}1.3 \pm 0.9 \\
\text { vs. } 1.3 \pm 0.7\end{array}$ & $\begin{array}{c}36.9 \pm 16.4 \\
\text { vs. } 47.0 \pm 19.2\end{array}$ \\
\hline Knight et al. [32] & $\begin{array}{l}12 / 130 \text { vs.17/129 } \\
\text { (VAP) }\end{array}$ & $\begin{array}{c}28 / 130 \\
\text { vs. } 34 / 129\end{array}$ & $\begin{array}{c}35 / 130 \\
\text { vs. } 42 / 129\end{array}$ & $\begin{array}{c}6(3-11) \\
\text { vs. } 7(3-14)\end{array}$ & $\begin{array}{l}19(3-36) \\
\text { vs. } 18(7-32)\end{array}$ \\
\hline Morrow et al. [22] & $\begin{array}{c}\text { 17/68vs. 33/70 } \\
\text { (VAP) }\end{array}$ & NA & $\begin{array}{c}12 / 68 \\
\text { vs. } 15 / 70\end{array}$ & $14.8 \pm 11.8$ vs. $14.6 \pm 11.6$ & $\begin{array}{c}21.4 \pm 14.9 \\
\text { vs. } 21.7 \pm 17.4\end{array}$ \\
\hline Rayes et al. [25] & $2 / 30$ vs. $6 / 30$ & NA & $\begin{array}{l}0 / 30 \\
\text { vs. } 0 / 30\end{array}$ & NA & $\begin{array}{c}14 \pm 4 \\
\text { vs. } 16 \pm 5.5\end{array}$ \\
\hline Rayes et al. [26] & $0 / 33$ vs. $1 / 33$ & NA & $\begin{array}{c}0 / 33 \\
\text { vs.0/33 }\end{array}$ & $\begin{array}{c}8.80 \pm 0.9 \\
\text { vs. } 10.2 \pm 1.8\end{array}$ & $\begin{array}{c}27.8 \pm 2.4 \\
\text { vs. } 27.9 \pm 2.1\end{array}$ \\
\hline Rayes et al. [27] & $0 / 40$ vs. $4 / 40$ & NA & $\begin{array}{c}1 / 40 \text { vs. 1/ } \\
40\end{array}$ & $2 \pm 3$ vs. $6 \pm 12$ & $17 \pm 8$ vs. $22 \pm 16$ \\
\hline Spindler-Vesel et al. [28] & $\begin{array}{c}\text { 4/26 vs. 34/87 } \\
\text { (VAP) }\end{array}$ & $\begin{array}{c}2 / 26 \\
\text { vs. } 5 / 87\end{array}$ & NA & NA & NA \\
\hline Tan et al.[29] & $9 / 22$ vs. $14 / 21$ & NA & $\begin{array}{c}0 / 22 \text { vs. 1/ } \\
21\end{array}$ & $\begin{array}{c}7.1 \pm 3.3 \\
\text { vs.11.3 } \pm 7.9\end{array}$ & NA \\
\hline
\end{tabular}

ICU: intensive care unit; NA: not available; NP: nosocomial pneumonia; VAP: ventilator-associated pneumonia. 


\begin{tabular}{|c|c|c|c|c|c|c|c|c|c|c|}
\hline Study or Subgroup & $\begin{array}{l}\text { Probiot } \\
\text { Events }\end{array}$ & $\begin{array}{l}\text { ics } \\
\text { Total }\end{array}$ & $\begin{array}{l}\text { Contrc } \\
\text { Events }\end{array}$ & $\begin{array}{l}\text { ol } \\
\text { Total }\end{array}$ & Weight & $\begin{array}{c}\text { Odds Ratio } \\
\text { M-H, Fixed, } 95 \% \mathrm{Cl}\end{array}$ & & $\begin{array}{r}\text { Odds } \\
\text { M-H, Fixe }\end{array}$ & $\begin{array}{l}\text { Ratio } \\
\text { d. } 95 \% \mathrm{Cl}\end{array}$ & \\
\hline Barraud2010 & 23 & 87 & 15 & 80 & $9.0 \%$ & $1.56[0.75,3.25]$ & & & 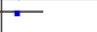 & \\
\hline Besselink2008 & 24 & 152 & 16 & 144 & $10.9 \%$ & $1.50[0.76,2.96]$ & & & - & \\
\hline Forestier2008 & 24 & 102 & 24 & 106 & $14.2 \%$ & $1.05[0.55,2.00]$ & & & $L_{-}$ & \\
\hline GiamarellosBourboulis2009 & 15 & 36 & 16 & 36 & $7.3 \%$ & $0.89[0.35,2.27]$ & & & & \\
\hline Kanazawa2005 & 0 & 21 & 1 & 23 & $1.1 \%$ & $0.35[0.01,9.04]$ & & & & \\
\hline Knight2009 & 12 & 130 & 17 & 129 & $12.2 \%$ & $0.67[0.31,1.47]$ & & $\rightarrow$ & & \\
\hline Morrow2010 & 17 & 68 & 33 & 70 & $19.2 \%$ & $0.37[0.18,0.77]$ & & & & \\
\hline Rayes2002 & 2 & 30 & 6 & 30 & $4.4 \%$ & $0.29[0.05,1.55]$ & & & & \\
\hline Rayes2005 & 0 & 33 & 1 & 33 & $1.2 \%$ & $0.32[0.01,8.23]$ & & & & \\
\hline Rayes2007 & 0 & 40 & 4 & 40 & $3.5 \%$ & $0.10[0.01,1.92]$ & & & - & \\
\hline Spindler-Vesel2007 & 4 & 26 & 34 & 87 & $10.4 \%$ & $0.28[0.09,0.89]$ & & & & \\
\hline Tan2011 & 9 & 22 & 14 & 21 & $6.7 \%$ & $0.35[0.10,1.20]$ & & & & \\
\hline Total $(95 \% \mathrm{Cl})$ & & 747 & & 799 & $100.0 \%$ & $0.75[0.57,0.97]$ & & 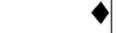 & & \\
\hline Total events & 130 & & 181 & & & & & & & \\
\hline $\begin{array}{l}\text { Heterogeneity: } \mathrm{Chi}^{2}=20.39 \text {, } \\
\text { Test for overall effect: } Z=2 \text {. }\end{array}$ & $\begin{array}{l}f=11(P= \\
(P=0.03\end{array}$ & $0.04)$ & $I^{2}=46 \%$ & & & & 0.01 & $\begin{array}{ll}0.1 & 1 \\
\text { probiotics }\end{array}$ & ${ }^{1}$ control $^{10}$ & 100 \\
\hline
\end{tabular}

Figure 2 Forest plot showing the effect of probiotics on the occurrence of nosocomial pneumonia (NP) in critical ill patients. Pooled ORs were calculated using the Mantel-Haenszel (M-H)Estimator. Study-level data were pooled using a random-effects model when $P^{2}$ was $>50 \%$ or a fixed-effects model when $P^{2}$ was $<50 \%$.

0.50 to $1.74, P=0.82$ ) (Figure 3 ). We did find evidence of statistical heterogeneity for in-hospital mortality $\left(I^{2}\right.$ $=51 \%, P=0.07)$. Only three of the twelve selected RCTs provided information regarding mortality during an ICU stay $[28,30,32]$. There was no significant difference in ICU mortality between a probiotics group and a placebo group $(\mathrm{OR}=0.84,95 \% \mathrm{CI} 0.55$ to $1.29, P=$ 0.43) (Figure 4$)$. There was no heterogeneity between trials $\left(I^{2}=0 \%\right)$.

\section{Duration of stay in the hospital}

Eight studies were included in the analysis of the length of stay in hospital [22,24-27,30,32,33]. There was no apparent effect of probiotics therapy on the duration of stay in hospital, with a mean difference (MD) of -0.13 days (95\% CI -0.93 to $0.67, P=0.75$ ) (Figure 5). A low level of heterogeneity was found among these comparisons $\left(I^{2}=46 \%, P=0.07\right)$.

\section{Duration of stay in the intensive care unit}

Data from eight studies were included in the analysis of the duration of stay in the intensive care unit
$[22,24,26,27,29,30,32,33]$. There was significant heterogeneity in length of ICU stays $\left(I^{2}=68 \%, P=0.002\right)$ (Figure 6). There was no significant difference between the compared groups regarding this outcome (MD in days $=-0.72,95 \% \mathrm{CI}-1.73$ to $0.29, P=0.16$ ).

\section{Adverse events}

The following adverse events were reported: diarrhea, abdominal cramps and bowel ischemia [22,25-27,32,33]. Data regarding the incidence of diarrhea were provided in six of the twelve included RCTs $[22,25-27,32,33]$. There was no difference between probiotics and placebo groups in the incidence of diarrhea $(\mathrm{OR}=0.85,95 \% \mathrm{CI} 0.58$ to $1.26, P=0.43, I^{2}=0 \%$ ). There was no significant difference between probiotics and placebo groups in the incidence of abdominal cramps in the meta-analysis that included only three RCTs $\left(\mathrm{OR}=0.74,95 \%\right.$ CI 0.47 to $1.17, P=0.19, I^{2}=$ $0 \%)[25,26,33]$.

\section{Publication bias}

Upon visual inspection of the funnel plot for the primary outcome, we found evidence of publication bias

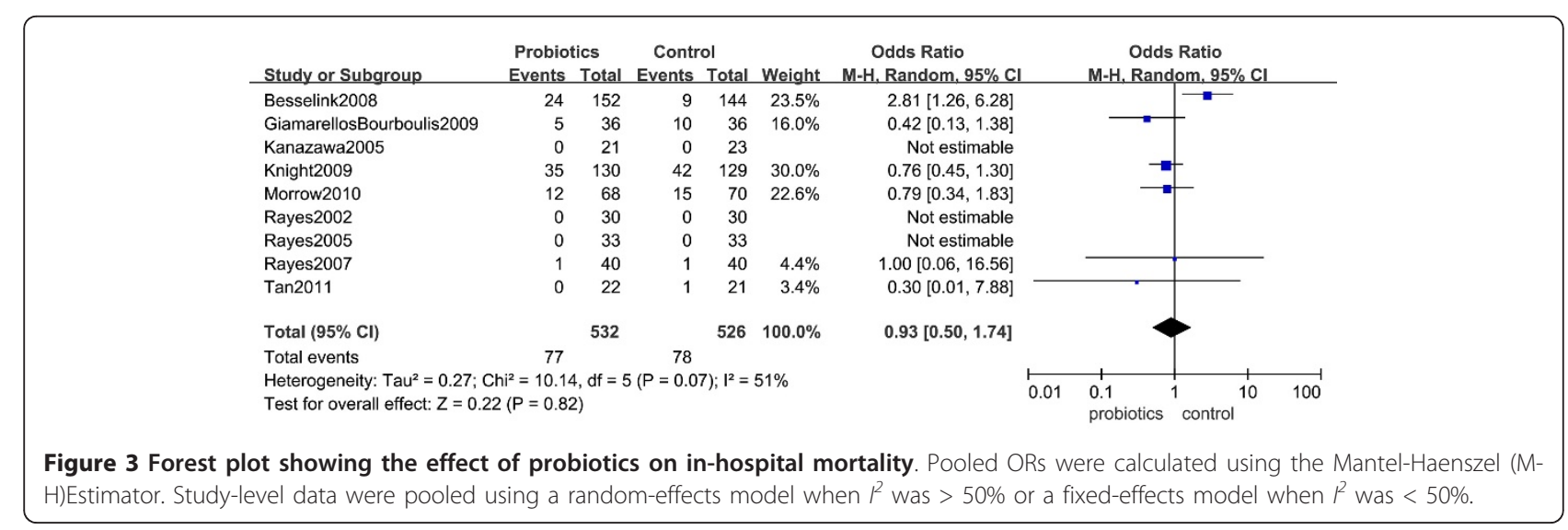




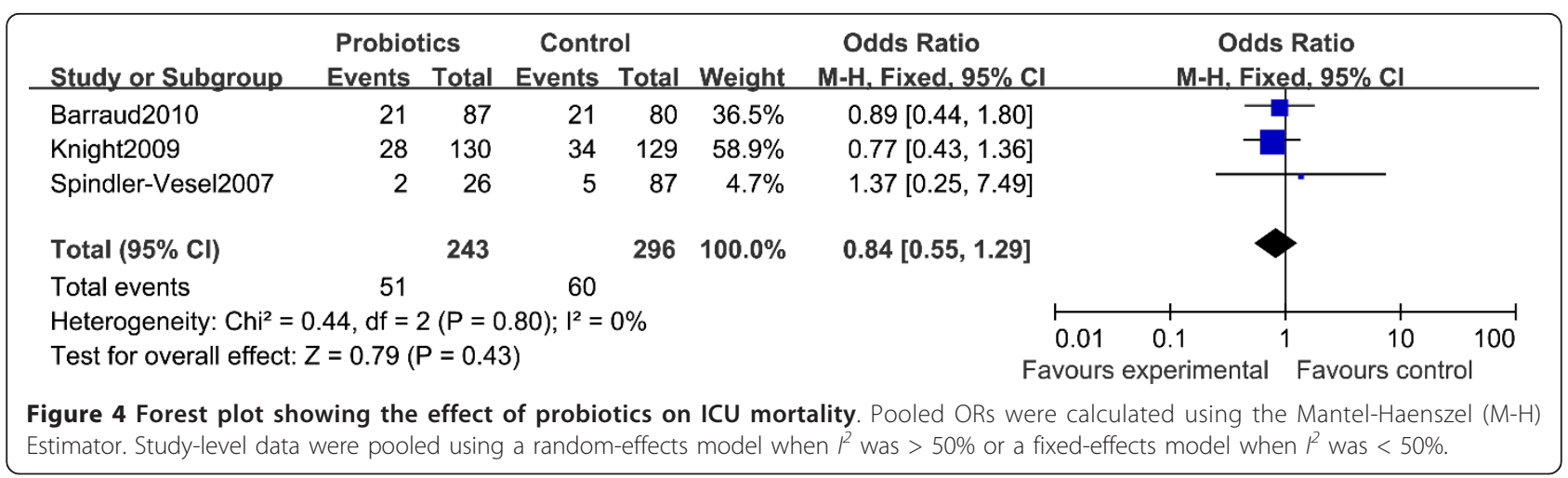

(absence of small studies, shown in the right lower corner of Figure 7).

\section{Discussion}

Our meta-analysis found that probiotics administration was associated with statistically significant reduction in the incidence of NP in critically ill patients. However, the pooled results showed that probiotics did not affect overall mortality, or length of stay in the hospital and the ICU, which were the secondary endpoints of the study.

The current meta-analysis is different from previous reviews in several aspects. Although three recent reviews addressed somewhat similar questions, our meta-analysis identified and included more eligible studies than the previous reviews [35-37]. These previous reviews on probiotics administration included studies that recruited patients requiring MV only [35] or studies of surgical patients only [36]. Thus, those meta-analyses were limited to selected populations. Trials of any type of critically ill patients were eligible for our study, and therefore our results are applicable across a wide range of clinical situations that are encountered with critically ill patients. In order to diminish the number of confounding factors, we excluded two studies using chlorhexidine and antibiotic decontamination as control groups, because the use of chlorhexidine in oral care procedures and antibiotic decontamination of the digestive tract were considered to be effective in preventing NP $[6,21]$. The review by Siempos et al. used the data from one trial on the rate of respiratory tract infection as the rate of VAP [35], which may have contributed to an overestimation of the VAP rate and a greater observed treatment effect. This trial has been recently published in a separate study [23] and confirms that there are fewer patients with VAP than with respiratory tract infections. Accordingly, we included the latter study in our meta-analysis. Our results appear similar to the previous reviews by Siempos et al. [35] and Pitsouni et al. [36], but inconsistent with the results of the systematic review by Watkinson et al. [37]. Siempos et al. found that administration of probiotics was beneficial in the incidence of both VAP and NP, length of stay in the ICU and colonization rates of Pseudomonas aeruginosa in the respiratory tract [35]. Similarly, the meta-analysis by Pitsouni et al. demonstrated that probiotics significantly reduced the occurrence of postoperative pneumonia and any infectious

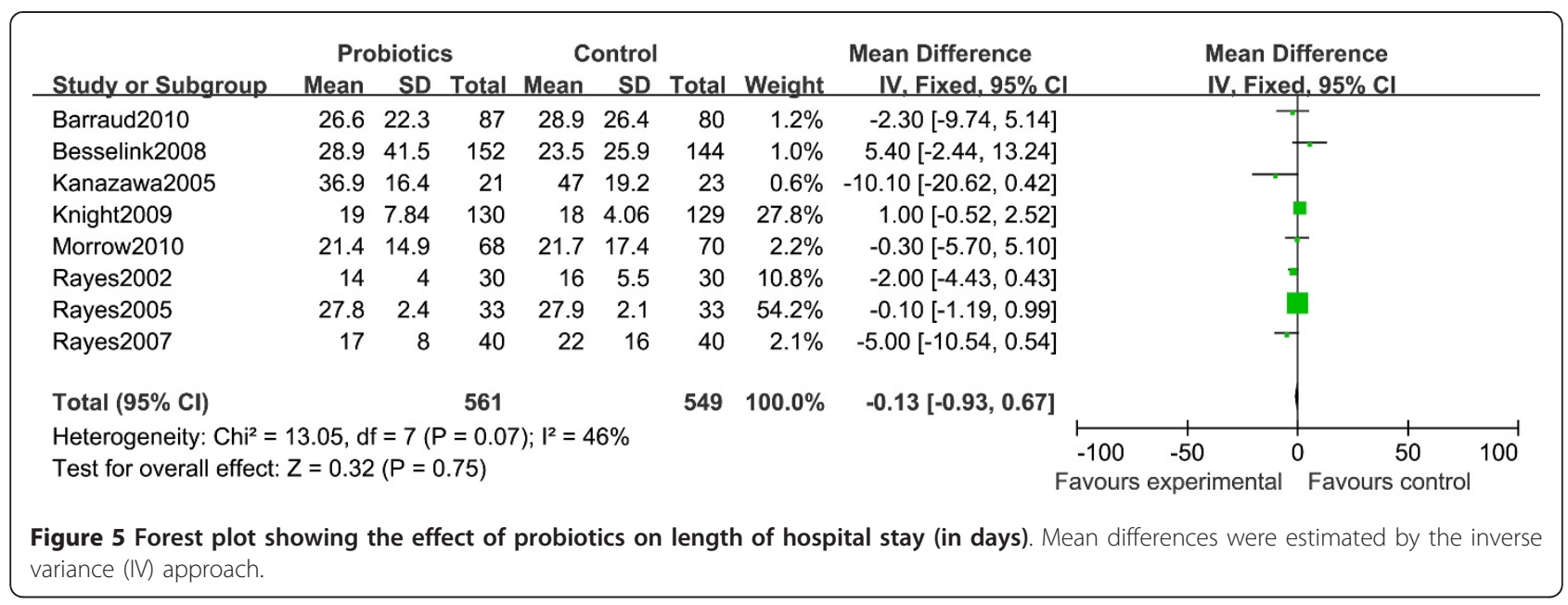




\begin{tabular}{|c|c|c|c|c|c|c|c|c|c|c|c|}
\hline \multirow[b]{2}{*}{ Study or Subgroup } & \multicolumn{3}{|c|}{ Probiotics } & \multicolumn{2}{|c|}{ Control } & \multirow[b]{2}{*}{ Total } & \multirow[b]{2}{*}{ Weight } & \multirow{2}{*}{$\begin{array}{l}\text { Mean Difference } \\
\text { IV. Random, } 95 \% \mathrm{Cl}\end{array}$} & \multirow{2}{*}{\multicolumn{3}{|c|}{$\begin{array}{c}\text { Mean Difference } \\
\text { IV. Random, } 95 \% \mathrm{Cl}\end{array}$}} \\
\hline & Mean & SD & Total & Mean & SD & & & & & & \\
\hline Barraud2010 & 18.7 & 12.4 & 87 & 20.2 & 20.8 & 80 & $3.3 \%$ & $-1.50[-6.75,3.75]$ & & & \\
\hline Besselink2008 & 6.6 & 17.1 & 152 & 3 & 9.3 & 144 & $7.9 \%$ & $3.60[0.49,6.71]$ & & $=$ & \\
\hline Kanazawa2005 & 1.3 & 0.9 & 21 & 1.3 & 0.7 & 23 & $29.0 \%$ & $0.00[-0.48,0.48]$ & & 1 & \\
\hline Knight2009 & 6 & 1.9 & 130 & 7 & 2.62 & 129 & $28.4 \%$ & $-1.00[-1.56,-0.44]$ & & & \\
\hline Morrow2010 & 14.8 & 11.8 & 68 & 14.6 & 11.6 & 70 & $5.5 \%$ & $0.20[-3.71,4.11]$ & & & \\
\hline Rayes2005 & 8.8 & 0.9 & 33 & 10.2 & 5.8 & 33 & $14.0 \%$ & $-1.40[-3.40,0.60]$ & & & \\
\hline Rayes2007 & 2 & 3 & 40 & 6 & 12 & 40 & $5.7 \%$ & $-4.00[-7.83,-0.17]$ & & $=$ & \\
\hline Tan2011 & 7.1 & 3.3 & 22 & 11.3 & 7.9 & 21 & $6.2 \%$ & $-4.20[-7.85,-0.55]$ & & $=$ & \\
\hline Total $(95 \% \mathrm{Cl})$ & & & 553 & & & 540 & $100.0 \%$ & $-0.72[-1.73,0.29]$ & & & \\
\hline \multicolumn{9}{|c|}{$\begin{array}{l}\text { Heterogeneity: } \text { Tau }^{2}=0.86 ; \mathrm{Chi}^{2}=22.08, d f=7(P=0.002) ; I^{2}=68 \% \\
\text { Test for overall effect: } Z=1.40(P=0.16)\end{array}$} & -100 & $\begin{array}{lll}-50 & 0 & 50 \\
\text { probiotics } & \text { control }\end{array}$ & 100 \\
\hline
\end{tabular}

Figure 6 Forest plot showing the effect of probiotics on length of ICU stay (in days). Mean differences were estimated by the inverse variance (IV) approach.

complications, as well as the duration of postoperative hospital stay [36]. While we restricted our subgroup analysis to patients in surgical populations, a pooled analysis showed a marginally non-significant reduction in NP in favor of probiotics. In contrast, Watkinson et al. pooled eight trials and found that pre- pro- or synbiotics were not associated with any significant change in the outcomes studied, that is, length of ICU stay, hospital mortality and the incidence of nosocomial infection and more specifically incidence of pneumonia [37]. Although there was no statistically significant effect on the incidence of NP in all subgroups, the risk reduction associated with probiotics use was substantial. The reasons for these inconsistent results may partly be due to differences in focus on clinical outcomes.
The results of this meta-analysis should be interpreted carefully based on other considerations. As the diagnosis of pneumonia is a more subjective outcome than mortality or length of stay in the ICU, it may be more subject to bias, and this may in part explain the marked reduction in pneumonia found in these studies. In addition, the definitions of pneumonia varied among different studies, which will affect the true nature of clinical outcomes. In addition, the absence of an effect on secondary outcomes may be from the small number of pooled RCTs and total patients. And lastly, the treatment durations in some studies were likely too short to demonstrate maximal benefits. Consequently, a lack of standard protocols and insufficient numbers of patients may make it difficult to derive conclusive results based on the current meta-analysis.

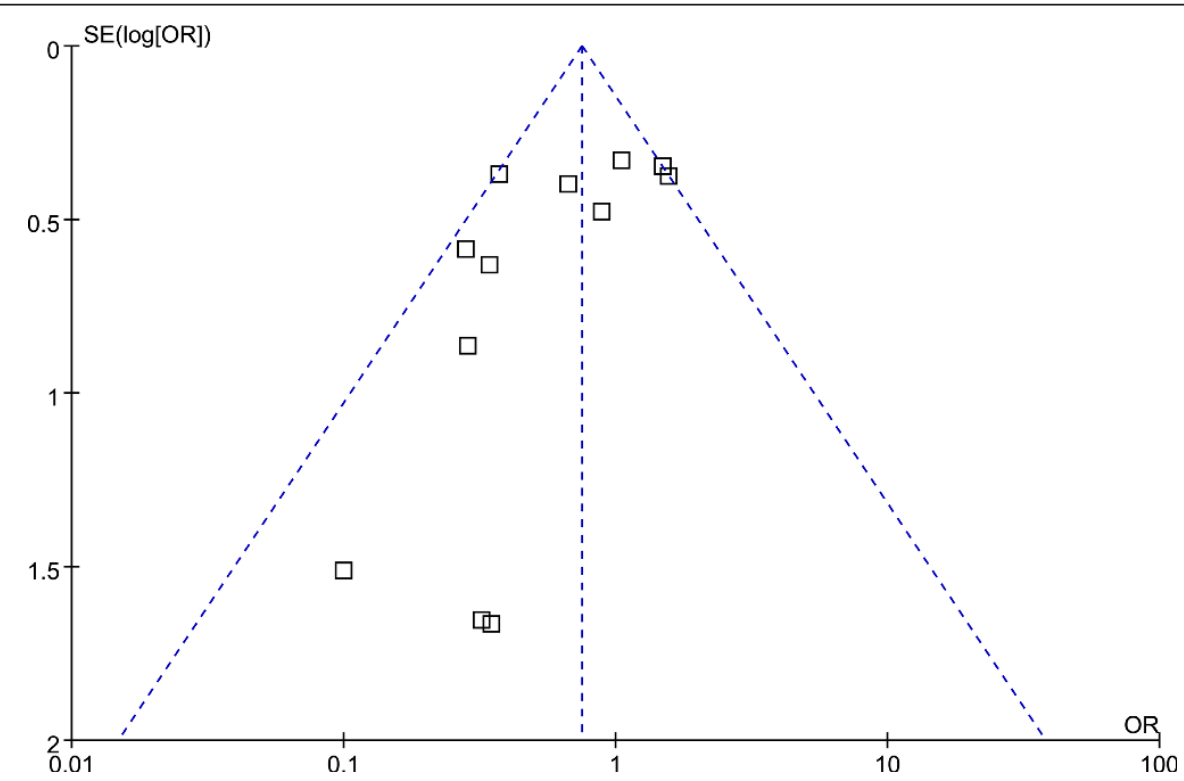

Figure 7 Funnel plot showing possibility of a small publication bias. SE, standard error: OR, odds ratio. 
The potential harm due to probiotics therapy also warrants comment. The numbers of patients with diarrhea or abdominal cramps did not differ between those patients who received probiotics and those who did not in our current meta-analysis. However, a particular concern in critically ill patients is whether their exposure to probiotics places them at risk for developing an invasive infection. There were no reports of bacteremia or sepsis due to probiotics in the studies included in our metaanalysis. In addition, Besselink et al. found an increased rate of bowel ischemia and mortality in those patients treated with probiotics [33]. However, a meta-analysis of four RCTs that included severe acute pancreatitis, including the study by Besselink et al. [38] demonstrated that probiotics did not significantly influence mortality either favorably or adversely. Accordingly, we should monitor the safety of probiotics as our research efforts move forward.

Our analysis has several limitations. First, as already mentioned, there was heterogeneity in the inclusion criteria, the populations studied, the probiotic agents used, doses, time points when therapy was initiated, durations of therapy, the routes of administration, and the diagnostic criteria used for establishing NP or VAP. These factors were not comparable in most of the trials and might have affected the clinical outcomes. These differences may explain the statistical heterogeneity in some of the secondary outcomes investigated. Second, even though we were able to pool results across all trials, the number of patients included in this meta-analysis may not be sufficient to exclude significant clinical benefit. Third, most trials were done in single centers and may have had inherent bias related to local practice habits and the populations served. Although we extensively searched for relevant studies using multiple databases and multiple search items, and no language restriction was placed on the search, a funnel plot suggested the possibility of publication bias. Finally, the quality of the included studies was not consistent. Some RCTs included in our analysis had major methodological flaws $[24,28]$. The quality of trials can affect the direction and magnitude of treatment effects when performing a meta-analysis.

Although the results have been encouraging, there is insufficient evidence to suggest to clinicians that administration of probiotics is associated with significant clinical benefit in critically ill patients. In addition, there is a lack of head-to-head comparative trials with different probiotics to investigate and clarify which probiotic bacterial strains were of most benefit to critically ill patients. Data regarding the superiority of different doses of probiotics and routes of administration are also lacking. The questions that remain to be evaluated in large-scale, randomized controlled trials of probiotics use in NP include the optimal type of probiotic preparation, administration route, dose intensity, timing and duration of administration, safety, patient eligibility, and contraindications.

\section{Conclusions}

The use of probiotics was associated with statistically significant reduction in the incidence of NP in critically ill patients. However, there is no evidence to support or refute claims of beneficial effects on clinically important outcomes. Large, well-designed, randomized, multi-center trials are needed to confirm the effects of probiotics in diverse populations of critically ill patients.

\section{Key messages}

- Numerous studies have examined the utility of probiotic therapy to prevent NP in critically ill patients, but studies on the use of probiotics have yielded mixed results.

- Probiotics administration was associated with statistically significant reduction in the incidence of NP in critically ill patients.

- More randomized control trials are needed to definitively determine the effect of probiotics in critically ill patients.

\section{Additional material}

Additional file 1: Forest plot showing the effect of probiotics on the occurrence of ventilator-assisted pneumonia in critical ill patients receiving mechanical ventilation.

Additional file 2: Forest plot showing the effect of probiotics on the occurrence of nocosomial pneumonia in I critically ill surgical patients

\section{Abbreviations}

APACHE: Acute Physiology and Chronic Health Evaluation; Cl: confidence interval; DB: double-blind; MC: multicenter; MD: mean difference; MV: mechanical ventilation; NA: not available; NP: nosocomial pneumonia; OR: odds ratio; RCTs: randomized control trials; SAPS: Simplified Acute Physiology Score; SC: single-center; T: temperature; VAP: ventilator-associated pneumonia.

\section{Acknowledgements}

This research was sponsored by the National Basic Research Program (973 Program) in China (2007CB513004), the Shanghai Subject Chief Scientist Program (07XD14012) and Shanghai Leading Talent Projects (No. 036, 2010).

\section{Author details}

'Department of Pulmonary Medicine, Huadong Hospital, Shanghai Medical School of Fudan University, 221 Yananxi Road, Shanghai 200040, China. ${ }^{2}$ Department of Pulmonary Medicine, Zhongshan Hospital, Shanghai Medical School of Fudan University, 180 Fenglin Road, Shanghai 200032, China.

${ }^{3}$ Department of Anesthesia \& Preoperative Care, University of California, San Francisco, 505 Parnassus Ave, San Francisco 94143, USA.

\section{Authors' contributions}

KXL and YGZ carried out the primary study search, extracted data, performed statistical analysis, and drafted and revised the manuscript. JZ 
drafted and revised the manuscript. LLT carried out statistical analysis and revised the manuscript. JWL revised the manuscript and modified the written English. XDW carried out statistical analysis and helped draft the manuscript. JMQ conceived the idea, participated in its design, and drafted and revised the manuscript. All authors read and approved the final manuscript.

\section{Competing interests}

The authors declare that they have no competing interests.

Received: 18 November 2011 Revised: 30 April 2012

Accepted: 25 June 2012 Published: 25 June 2012

\section{References}

1. Kollef MH: Prevention of hospital-associated pneumonia and ventilatorassociated pneumonia. Crit Care Med 2004, 32:1396-1405.

2. American Thoracic Society and Infections Diseases Society of America: Guidelines for the management of adults with hospital-acquired, ventilator-associated pneumonia, and healthcare associated pneumonia. Am J Respir Crit Care Med 2005, 171:388-416.

3. Safdar N, Dezfulian C, Collard HR, Saint S: Clinical and economic consequences of ventilator-associated pneumonia: A systematic review. Crit Care Med 2005, 33:2184-2193.

4. Estes RJ, Meduri GU: The pathogenesis of ventilator-associated pneumonia: I. Mechanisms of bacterial transcolonisation and airway inoculation. Intensive Care Med 1995, 21:365-383.

5. Oostdijk EA, de Smet AM, Blok HE, Thieme Groen ES, van Asselt GJ, Benus RF, Bernards SA, Frenay IH, Jansz AR, de Jongh BM, Kaan JA, Leverstein-van Hall MA, Mascini EM, Pauw W, Sturm PD, Thijsen SF, Kluytmans JA, Bonten MJ: Ecological effects of selective decontamination on resistant Gram-negative bacterial colonization. Am J Respir Crit Care Med 2010, 181:452-457.

6. Oudhuis GJ, Bergmans DC, Dormans T, Zwaveling J-H, Kessels A, Prins MH Stobberingh EE, Verbon A: Probiotics versus antibiotic decontamination of the digestive tract: infection and mortality. Intensive Care Med 2011, 37:110-117.

7. Wolvers D, Antoine JM, Myllyluoma E, Schrezenmeir J, Szajewska $H$, Rijkers GT: Guidance for substantiating the evidence for beneficial effects of probiotics: prevention and management of infections by probiotics. J Nutr 2010, 140:698S-712S.

8. Schultz MJ, Haas LE: Antibiotics or probiotics as preventive measures against ventilator-associated pneumonia: a literature review. Critical Care 2011, 15:R18.

9. Isakow W, Morrow LE, Kollef : Probiotics for preventing and treating nosocomial infections: review of current evidence and recommendations. Chest 2007, 132:286-294.

10. McNabb B, Isakow W: Probiotics for the prevention of nosocomial pneumonia: current evidence and opinions. Curr Opin Pulm Med 2008, 14:168-175.

11. Joint FAO/WHO working group. Guidelines for the evaluation of probiotics in food: report of a joint FAOWHO working group on drafting guidelines for the evaluation of probiotics in food London, Ontario, Canada; 2002.

12. Walker WA: Mechanisms of action of probiotics. Clin Infect Dis 2002, 46(Suppl 2):S87-S91.

13. Forsythe P: Probiotics and lung diseases. Chest 2011, 139(4):901-908.

14. Isolauri E, Sutas Y, Kanaanpaa P, Arvilommi H, Salminen S: Probiotics: effects on immunity. Am J Clin Nutr 2001, 73:444S-450S.

15. Alberda C, Gramlich L, Meddings J, Field C, McCargar L, Kutsogiannis D, Fedorak $R$, Madsen $K$ : Effects of probiotic therapy in critically ill patients: a randomized, double-blind, placebo-controlled trial. Am J Clin Nutr 2007, 85:816-823.

16. Van Minnen LP, Timmerman HM, Lutgendorff F, Verheem A, Harmsen W, Konstantinov SR, Smidt H, Visser MR, Rijkers GT, Gooszen HG, Akkermans $L M$ : Modification of intestinal flora with multispecies probiotics reduce bacterial translocation and improve clinical course in rat model of acute pancreatitis. Surgery 2006, 141:470-480.

17. Madsen K, Cornish A, Soper P, McKaigney C, Jijon H, Yachimec C, Doyle J, Jewell $L$, De Simone C: Probiotic bacteria enhance murine and human intestinal epithelial barrier function. Gastroenterology 2001, 121:580-591.

18. Ewaschuk J, Endersby R, Thiel D, Diaz H, Backer J, Ma M, Churchill T, Madsen K: Probiotic bacteria prevent hepatic damage and maintain colonic barrier function in a mouse model of sepsis. Hepatology 2007, 46:841-850.

19. Zhou HJ, Yin L, Chen CQ, Shi MM, Zhang MJ: Administration of probiotics reduces bacterial translocation after intestinal transplantation in rats. Transplantation Proceedings 2010, 42:4643-4647.

20. Kotzampassi K, Giamarellos-Bourboulis EJ, Voudouris A, Kazamias P, Eleftheriadis E: Benefits of a synbiotic formula (Synbiotic 2000Forte) in critically ill trauma patients: early results of a randomized controlled trial. World J Surg 2006, 30:1848-1855.

21. Klarin B, Molin G, Jeppson B, Larsson A: Use of the probiotic Lactobacillus plantarum 299 to reduce pathogenic bacteria in the oropharynx of intubated patients: a randomized controlled open pilot study. Crit Care 2008, 12:R136

22. Morrow LE, Kollef MH, Casale TB: Probiotic prophylaxis of ventilatorassociated pneumonia: a blinded, randomized, controlled trial. Am J Respir Crit Care Med 2010, 182:1058-1064.

23. Giamarellos-Bourboulis EJ, Bengmark S, Kannellakopoulou K, Kotzampassi K: Pro- and synbiotics to control inflammation and infection in patients with multiple injuries. J Trauma 2009, 67:815-821.

24. Kanazawa H, Nagino M, Kamiya S, Komatsu S, Mayumi T, Takagi K, Asahara T, Nomoto K, Tanaka R, Nimura Y: Synbiotics reduce postoperative infectious complications: a randomized controlled trial in biliary cancer patients undergoing hepatectomy. Langenbecks Arch Surg 2005, 390:104-113.

25. Rayes N, Hansen S, Seehofer D, Muller AR, Serke S, Bengmark S, Neuhaus P: Early enteral supply of fiber and Lactobacilli versus conventional nutrition: a controlled trial in patients with major abdominal surgery. Nutrition 2002, 18:609-615.

26. Rayes N, Seehofer D, Theruvath T, Schiller RA, Langrehr JM, Jonas S, Bengmark S, Neuhaus P: Supply of pre- and probiotics reduces bacterial infection rates after liver transplantation: a randomized, double-blind trial. Am J Transplant 2005, 5:125-130.

27. Rayes N, Seehofer D, Theruvath T, Mogl M, Langrehr JM, Nüssler NC, Bengmark S, Neuhaus P: Effect of enteral nutrition and synbiotics on bacterial infection rates after pylorus-preserving pancreatoduodenectomy. Ann Surg 2007, 246:36-40.

28. Spindler-Vesel A, Bengmark S, Vovk I, Cerovic O, Kompan L: Synbiotics, prebiotics, glutamine, or peptide in early enteral nutrition: a randomized study in trauma patients. J Parenter Enteral Nutr 2007, 31:119-126.

29. Tan M, Zhu JC, Du J, Zhang LM, Yin HH: Effects of probiotics on serum levels of Th1/Th2 cytokine and clinical outcomes in severe traumatic brain-injured patients: a prospective randomized pilot study. Critical Care 2011, 15:R290

30. Barraud D, Blard C, Hein F, Marçon O, Cravoisy A, Nace L, Alla F, Bollaert PE, Gibot S: Probiotics in the critically ill patient: a double blind, randomized, placebo-controlled trial. Intensive Care Med 2010, 36:1540-1547.

31. Forestier C, Guelon D, Cluytens V, Guillart T, Sirot J, De champs C: Oral probiotic and prevention of Pseudomonas aeruginosa infections: a randomized, double-blind, placebocontrolled pilot study in intensive care unit patients. Crit Care 2008, 12:R69.

32. Knight DJ, Gardiner D, Banks A, Snape SE, Weston VC, Bengmark S, Girling KJ: Effect of synbiotic therapy on the incidence of ventilator associated pneumonia in critically ill patients: a randomised, doubleblind, placebo-controlled trial. Intensive Care Med 2009, 35:854-861.

33. Besselink MG, van Santvoort HC, Buskens E, Boermeester MA, van Goor H, Timmerman HM, Nieuwenhuijs VB, Bollen TL, van Ramshorst B, Witteman BJ, Rosman C, Ploeg RJ, Brink MA, Schaapherder AF, Dejong CH, Wahab PJ, van Laarhoven CJ, van der Harst E, van Eijck CH, Cuesta MA, Akkermans LM, Gooszen HG, Dutch Acute Pancreatitis Study Group: Probiotic prophylaxis in predicted severe acute pancreatitis: a randomised, double-blind, placebo-controlled trial. Lancet 2008, 371:651-659.

34. Jadad AR, Moore RA, Carroll D, Jenkinson C, Reynolds DJ, Gavaghan DJ, McQuay HJ: Assessing the quality of reports of randomized clinical trials: is blinding necessary? Control Clin Trials 1996, 17:1-12.

35. Siempos II, Ntaidou TK, Falagas ME: Impact of the administration of probiotics on the incidence of ventilator-associated pneumonia: a metaanalysis of randomized controlled trials. Crit Care Med 2010, 38:954-962.

36. Pitsouni E, Alexious V, Saridakis V, Peppas G, Falagas ME: Does the use of probiotics/synbiotics prevent postoperative infections in patients 
undergoing abdominal surgery? A meta-analysis of randomized controlled trials. Eur J Pharmacol 2009, 65:561-570.

37. Watkinson PJ, Barber VS, Dark P, Young JD: The use of pre-pro- and synbiotics in adult intensive care unit patients: systemic review. Clin Nutr 2007, 26:82-192.

38. Sun S, Yang K, He X, Tian J, Ma B, Jiang L: Probiotics in patients with severe acute pancreatitis: a meta-analysis. Langenbecks Arch Surg 2008 394:171-177.

doi:10.1186/cc11398

Cite this article as: Liu et al:: Probiotics' effects on the incidence of nosocomial pneumonia in critically ill patients: a systematic review and meta-analysis. Critical Care 2012 16:R109.

Submit your next manuscript to BioMed Central and take full advantage of:

- Convenient online submission

- Thorough peer review

- No space constraints or color figure charges

- Immediate publication on acceptance

- Inclusion in PubMed, CAS, Scopus and Google Scholar

- Research which is freely available for redistribution

Submit your manuscript at www.biomedcentral.com/submit 